\title{
Lack of Genetic Relatedness Between Mycoplasma alvi and Mycoplasma sualvi
}

\author{
GUNNA CHRISTIANSEN,${ }^{1}$ CLAUS CHRISTIANSEN,${ }^{2}$ AND EYVIND A. FREUNDT ${ }^{1 *}$ \\ Institute of Medical Microbiology, University of Aarhus, DK-8000 Aarhus $C{ }^{1}$ and The Genetechnology Group, The \\ Technical University of Denmark, DK-2800 Lyngby, ${ }^{2}$ Denmark
}

\begin{abstract}
In hybridization experiments performed with deoxyribonucleic acids extracted from the type strains of Mycoplasma alvi and Mycoplasmá sualvi, no hybridization was demonstrated. A representative strain (strain 1161-III) of a supposedly new species that exhibited some resemblance to $M$. alvi especially showed levels of deoxyribonucleic acid-deoxyribonucleic acid relatedness of less than $4 \%$ with both species.
\end{abstract}

Mycoplasma alvi Gourlay, Wyld and Leach 1977 (3) and Mycoplasma sualvi Gourlay, Wyld and Leach 1978 (4) share a number of prominent characteristics. The cells of both species are predominantly flask or club shaped with more or less well defined polar structures that probably serve as attachment organelles. In $M$. alvi each organelle contains a rod-shaped central core, which has not been demonstrated in $M$. sualvi. Although $M$. alvi and $M$. sualvi are facultative anaerobes, the growth of both organisms is better under anaerobic conditions. The biochemical properties of these two species, including utilization of glucose and arginine, are likewise identical. $M$. alvi is a common inhabitant of bovine alimentary and urogenital tracts, whereas $M$. sualvi occupies a similar ecological niche in pigs. Serologically, the two species are distinct. The guanine-plus-cytosine contents of the deoxyribonucleic acids (DNAs) of $M$. alvi and $M$. sualvi are 26.4 and 23.7 mol\% (buoyant density method), respectively, and thus demonstrate a significant difference between the two species $(3,4)$.

The purpose of this study was to examine the degree of genetic relatedness between $M$. alvi and $M$. sualvi by using DNA-DNA hybridization. Our study was further prompted by the observation of a serological one-way cross-reaction between $M$. alvi and the representative strain (strain 1161-III) of a supposedly new species isolated from cell cultures. Strain 1161-III resembles $M$. alvi and $M$. sualvi in its ability to degrade both glucose and arginine and in possessing a polar terminal structure containing a central dense core $(M$. Salih, O. Vinther, and E. A. Freundt, unpublished observations). To determine the significance of the phenotypic similarities between $M$. alvi or $M$. sualvi and strain 1161-III, we decided to include this strain in the hybridization experiments.

The strains examined in this study are listed in Table 1. Anaeroplasma sp. strain 161, Mycoplasma hominis PG $21^{\mathrm{T}}$ ( $\mathrm{T}=$ type strain), and Mycoplasma mycoides subsp. mycoides $\mathrm{PG}^{\mathrm{T}}$ were included for comparison. Culture material of Anaeroplasma sp. strain 161 was provided by I. M. Robinson, National Animal Disease Center, Ames, Iowa, and the other strains were type or reference strains kept at the Food and Agriculture Organization/World Health Organization Collaborating Centre for Animal Mycoplasmas, University of Aarhus, Aarhus, Denmark.

DNA was extracted as previously described (2). The guanine-plus-cytosine content of the DNA of Mycoplasma sp. strain 1161-III was determined by the method of Schild

\footnotetext{
* Corresponding author.
}

TABLE 1. Hybrid yields (percentages of homologous reactions) with DNA-DNA hybrids of Mycoplasma and Anaeroplasma species

\begin{tabular}{lccc}
\hline \multirow{2}{*}{ [ $\left.^{3} \mathrm{H}\right] \mathrm{DNA}$ in solution } & \multicolumn{3}{c}{ DNA on filter } \\
\cline { 2 - 4 } & $\begin{array}{c}\text { M. alvi } \\
\text { Ilsley }^{\mathrm{T}}\end{array}$ & $\begin{array}{c}M . \text { sualvi } \\
\text { Mayfield }^{\mathrm{T}}\end{array}$ & $\begin{array}{c}\text { Mycoplasma sp. } \\
\text { strain 1161-III }\end{array}$ \\
\hline M. alvi Ilsley & 100 & 0 & 2.4 \\
M. sualvi Mayfield & 0 & 100 & 0 \\
Mycoplasma sp. strain 1161-III & 3.3 & 0.2 & 100 \\
M. hominis PG21 & 1.2 & 1.4 & 0 \\
M. mycoides subsp. mycoides & 0.3 & 0.3 & 0 \\
PG1 $^{\mathrm{T}}$ & & 0.3 & 0 \\
Anaeroplasma sp. strain 161 & 0 & 0.3 & 0 \\
\hline
\end{tabular}

${ }^{a}$ Results are expressed as percentages of homologous reactions. Actual counts in homologous reactions were about $5,000 \mathrm{cpm}$; blank reactions were $150 \mathrm{cpm}$.

kraut et al. (5). DNA extracted from Escherichia coli was used as a reference (buoyant density, $1.7100 \mathrm{~g} / \mathrm{cm}^{3}$ ). DNADNA hybridization experiments were performed as described previously by a membrane filter method $(1,2)$.

The buoyant density of the DNA of Mycoplasma sp. strain 1161-III was $1.6837 \mathrm{~g} / \mathrm{cm}^{3}$ (standard deviation, 0.0001 ; $n=2$ ); this gave a calculated value for the guanine-pluscytosine content of $24.2 \pm 0.1 \mathrm{~mol} \%$.

The results of the DNA-DNA hybridization experiments are shown in Table 1 , which shows that no or only very insignificant hybridization occurred among the test strains.

In conclusion, our data confirm the mutual taxonomic distinctness of $M$. alvi and $M$. sualvi. Moreover, our data show that Mycoplasma sp. strain 1161-III is genetically unrelated to either of these species.

\section{LITERATURE CITED}

1. Christiansen, C., G. Askaa, E. A. Freundt, and R. F. Whitcomb. 1979. Nucleic acid hybridization experiments with Spiroplasma citri and the cornstunt and suckling mouse cataract spiroplasmas. Curr. Microbiol. 2:323-326.

2. Christiansen, C., F. T. Black, and E. A. Freundt. 1981. Hybridization experiments with deoxyribonucleic acid from Ureaplasma urealyticum serovars I to VIII. Int. J. Syst. Bacteriol. 31:259-262.

3. Gourlay, R. N., S. G. Wyld, and R. H, Leach. 1977. Mycoplasma $a l v i$, a new species from bovine intestinal and urogenital tracts. Int. J. Syst. Bacteriol. 27:86-96.

4. Gourlay, R. N., S. G. Wyld, and R. H. Leach. 1978. Mycoplasma sualvi, a new species from the intestinal and urogenital tracts of pigs. Int. J. Syst. Bacteriol. 28:289-292.

5. Schildkraut, C. L., J. Marmur, and P. Doty. 1962. Determination of the base composition of deoxyribonucleic acid from its buoyant density in CsCl. J. Mol. Biol. 4:430-443. 